Reddy, S.M., Timms, N.E., Hamilton, P.J \& Smyth, H.S. 2009. Crystal Plastic Deformation of Zircon in a Magma Chamber. Contributions to Mineralogy and Petrology, 157, 231-244.

\title{
Deformation-Related Microstructures in Magmatic Zircon and Implications for Diffusion
}

\author{
Steven M. Reddy ${ }^{1 *} \cdot$ Nicholas E. Timms $^{1} \cdot$ P. Joseph Hamilton ${ }^{1 \dagger} \cdot$ Helen R. Smyth $^{2}$ \\ ${ }^{1}$ The Institute for Geoscience Research, Dept of Applied Geology, Curtin University of \\ Technology, GPO Box U1987, Perth, WA 6845, Australia \\ ${ }^{2}$ CASP, Department of Earth Sciences, University of Cambridge, CB3 ODH, U.K. \\ †Now at: Intellection Pty. Ltd., 27 Mayneview Street, Milton, Queensland, 4064, Australia
}

Key Words: arc magmatism; cumulate; Electron Backscatter Diffraction (EBSD); cathodoluminescence; crystal plasticity; dislocation creep

* Corresponding author.

E-mail address: $\underline{\text { S.Reddy@curtin.edu.au }}$

fax: +61-8-9266-3153

Tel.:+61-8-9266-4371 


\section{Introduction}

The mineral zircon $\left(\mathrm{ZrSiO}_{4}\right)$ is physically and chemically robust and accommodates a wide range of trace elements into its lattice. These trace elements provide information on the petrogenetic processes associated with zircon growth (Hoskin and Schaltegger 2003) and facilitate geochronological dating via a number of different radiometric decay systems (Davis et al. 2003; Dickin 2005; Kinny and Maas 2003; Reiners 2005). As a result, the geochemical analysis of zircon provides constraints on a range of important geological processes.

Underpinning its widespread application are the results of volume diffusion experiments that yield diffusion parameters which indicate that the chemical modification of zircon is unlikely below $900^{\circ} \mathrm{C}$, i.e. under most crustal temperature conditions (Cherniak and Watson 2003). However, recent electron backscatter diffraction (EBSD) studies show that zircon may deform by crystal plasticity within the Earth's crust (Reddy et al. 2007). Such deformation yields microstructures that act as fast diffusion pathways that enhance bulk diffusion rates and facilitate the modification of zircon chemistry (rare earth element, $\mathrm{U}$ and $\mathrm{Th}$ ) at crustal conditions (Reddy et al. 2006; Timms et al. 2006). These previous microstructural and chemical studies were undertaken on anomalously large natural zircons that may not be representative of typical igneous zircon. Consequently it remains unclear whether the generally smaller igneous zircons routinely used for geochemical analysis could develop and record dislocation-related crystal plasticity.

Here we present quantitative microstructural (EBSD) data from zircon collected from an undeformed igneous rock from Java, Indonesia, which show that processes associated with magmatic crystallization may lead to the crystal plastic deformation of zircon. We then consider the significance of such microstructures for studies of zircon geochemistry and geochronology from a range of different geological environments. 


\section{Sample Characteristics}

The studied sample (Jhs2Pon4) is an igneous rock located to the southeast of Lawu volcano close to the boundary of the Southern Mountains Arc and modern Sunda Arc of the Ponorogo

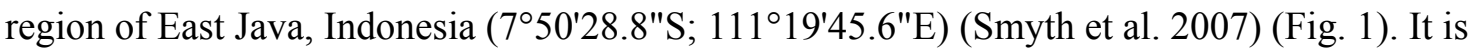
an undeformed glomeroporphyritic andesite that intrudes into the Eocene - Early Miocene Southern Mountains Arc and overlying carbonates at shallow crustal levels. Previous work in the region has identified a gap in volcanic activity from $c .18$ - $10 \mathrm{Ma}$, when arc volcanism resumed to the north of the Southern Mountains Arc along the axis of the modern Sunda Arc (Smyth et al. 2008). Given this history and observed field relationships, the studied andesite appears to be related to the activity of the modern Sunda Arc and not the Southern Mountains Arc (Smyth et al. 2008; Smyth et al. 2007). This is confirmed by the geochronological data presented later.

The studied andesite contains glomerocrysts comprising interlocking grains of either plagioclase and/or hornblende. Grains making up the glomerocrysts are compositionally zoned and have sieve-textured rims (Fig. 2a,b). Within glomerocrysts, boundaries between plagioclase grains are commonly curved (Fig. 2a), and occasionally impingement textures are preserved within hornblende grains (Fig. 2b). The glomerocrysts have adcumulate textures that indicate almost complete crystallisation of initial melt phase with melt fractions $<5 \%$ (Fig. 2). Undulose extinction, deformation twinning and transgranular fracture are observed within the plagioclase glomerocrysts (Fig. 2a,c,d), though these features have not been seen in the less common amphibole glomerocrysts. Where observed, zircon is seen to lie along boundaries or at the triple junction of plagioclase grains that form the glomerocrysts (Fig. 2d). 
As well as the course grains preserved within glomerocrysts, smaller phenocrysts of

plagioclase and hornblende are preserved in the matrix (Fig. 2). These grains commonly have a grain diameter of $\sim 150 \mu \mathrm{m}$ and are distinct from the finer grains $(\sim 20 \mu \mathrm{m})$ that make up the groundmass. Clear plagioclase rims overgrow sieve-textured plagioclase crystals at the glomerocryst margins (Fig. 2a) and surround skeletal cores of the smaller phenocrysts in the matrix.

\section{Analytical Procedure}

Zircon was separated from a crushed rock sample using magnetic and methylene iodide liquid separation. Grains were handpicked and mounted in an epoxy resin disc. The mount was then manually polished using progressively finer grades of diamond paste (down to $1 \mu \mathrm{m}$ ) on a cloth lap. Following this mechanical polishing the sample was polished for a further 4 hours with $0.06 \mu \mathrm{m}$ colloidal silica in a $\mathrm{NaOH}$ solution $(\mathrm{pH} 10)$ on a Vibromet II polisher to remove mechanically-induced surface damage.

Panchromatic cathodoluminescence (PCL), orientation contrast imaging and EBSD were undertaken on a Phillips XL30 SEM housed at the Microstructural Analysis Facility of Curtin University of Technology, part of the Nanoscale Characterisation Centre WA. PCL imaging was undertaken using a KE Developments CL system operating at $12 \mathrm{kV}$ and working distance of $15 \mathrm{~mm}$. PCL images were collected in the 330-600nm spectral range. Electron backscatter patterns (EBSPs) were collected using a Nordlys I EBSD detector. Orientation contrast images were collected from two forescatter detectors that are integrated into the Nordlys detector. For EBSD and orientation contrast imaging the sample was coated with a thin layer of carbon (c. $2 \mathrm{~nm})$ to prevent charging in the SEM. Orientation contrast images and 
EBSD data were collected, following the procedure described in detail for zircon (Reddy et al. 2007).

SEM settings used for EBSD collection are documented in Table 1. Acquisition of EBSD data was undertaken using Oxford Instruments Channel 5.9 Flamenco software using the parameters also documented in Table 1. For each zircon grain, automatic EBSD mapping was undertaken by collecting an EBSP (Fig. 3a) from each node of a user-defined, $1 \mu \mathrm{m}$ grid. For each EBSP, a Hough Transform (Hough 1962) was used to select the 8 strongest diffraction bands and these were then compared to a theoretical zircon diffraction pattern (match unit). Following detailed examination of zircon theoretical match units (Reddy et al. 2008), empirically-derived diffraction patterns were indexed using a match unit corresponding to the zircon crystal structure at 9.8 Atm ( $\equiv 1 \mathrm{MPa}$ ) (Hazen and Finger 1979), recorded as card 5261 in the Mincryst crystallographic database (Chichagov et al. 2001). The theoretical reflector intensity file for this zircon structure was calculated from structure factor calculations using Channel 5 Twist software. Comparison of the angular "closeness of fit" between the empirically obtained pattern and the theoretical solution (shown visually in Fig 3b), was recorded for each EBSP by the mean angular deviation (MAD) of the patterns. In all cases the MAD was low $\left(<<1.3^{\circ}\right)$ indicating a high degree of fit between theoretical and empirical EBSPs. The EBSD data were noise reduced using a "wildspike" correction and a fourneighbour zero solution extrapolation following standard procedures (Reddy et al. 2007). Data were also passed once through a modified Kuwahara filter $\left(3 \times 3\right.$ filter size with $5^{\circ}$ smoothing angle and $1^{\circ}$ artefact angle). This has the affect of reducing angular noise in orientation maps (Humphreys et al. 2001).

The EBSD data from each zircon were processed to produce a series of maps that show different aspects of the microstructure. Principally two types of maps were used. Cumulative 
misorientation maps show progressive changes in crystal lattice orientation and are derived by comparing the orientations derived from all EBSPs to a user-defined reference orientation (Fig. 3c). Local misorientation maps show the positions of orientation boundaries and are derived by calculating the mean misorientation angle between an EBSP and its immediate 8 neighbours and assigning this value to the central grid node (Fig 3d). All orientation maps were created using the Channel 5.9 "Tango" software module.

Crystallographic orientation and misorientation data were plotted using Channel 5.9 "Mambo" software using lower hemisphere, equal area projections. All data are reported with respect to an arbitrarily assigned $\mathrm{X}-\mathrm{Y}$ coordinate framework for the sample surface that is also shown in each of the orientation maps. The tetragonal crystal symmetry of zircon means that eight possible misorientation angle/axes may be calculated between two different crystallographic orientations (Grimmer 1980). In this study, the angle/axis pair corresponding to the minimum misorientation angle was used for analysis since intragrain variations in crystallographic orientation are progressive.

For isotopic analyses, the mount was sputter-coated with a thin coat of gold, sufficient to produce a resistivity of 10-20 ohms across the disc. Zircon U-Pb isotopic data were collected using the Sensitive High Resolution Ion Microprobe (SHRIMP II) based in the John de Laeter Centre of Mass Spectrometry, Perth, Western Australia. The sensitivity for Pb isotopes in zircon using SHRIMP II over the period of analysis was $\sim 18 \mathrm{cps} / \mathrm{ppm} / \mathrm{nA}$, the primary beam current was 2.5-3.0 nA and mass resolution was $\sim 5000 . \mathrm{Pb} / \mathrm{U}$ isotopic ratios were corrected for instrumental inter-element discrimination using the observed covariation between $\mathrm{Pb}+/ \mathrm{U}+$ and $\mathrm{UO}+/ \mathrm{U}+$ (Compston et al. 1984; Hinthorne et al. 1979) determined from interspersed analyses of the CZ3 zircon standard. This standard is a single crystal zircon 
megacryst from Sri Lanka and has a ${ }^{206} \mathrm{~Pb} /{ }^{238} \mathrm{U}=0.0914,{ }^{206} \mathrm{~Pb} /{ }^{238} \mathrm{U}$ age of $564 \mathrm{Ma}$ and a $\mathrm{U}$ content of 550 ppm (Nelson 1997).

Following standard $\mathrm{U} / \mathrm{Pb}$ dating procedures, the dates from individual analyses were corrected based on different isotopic ratios, that is ${ }^{208} \mathrm{~Pb}$ corrected ${ }^{206} \mathrm{~Pb} /{ }^{238} \mathrm{U},{ }^{204} \mathrm{~Pb}$ corrected ${ }^{206} \mathrm{~Pb} /{ }^{238} \mathrm{U}$ and ${ }^{204} \mathrm{~Pb}$ corrected ${ }^{207} \mathrm{~Pb} /{ }^{206} \mathrm{~Pb}$ for date ranges of $<100 \mathrm{Ma}, 100-1250 \mathrm{Ma}$ and $>$ $1250 \mathrm{Ma}$ respectively. Correction of measured isotopic ratios for common $\mathrm{Pb}$ was based on the measured ${ }^{204} \mathrm{~Pb}$ and was modelled on the composition of Broken Hill ore $\left({ }^{204} \mathrm{~Pb} /{ }^{206} \mathrm{~Pb}=\right.$ $\left.0.0625 ;{ }^{207} \mathrm{~Pb} /{ }^{206} \mathrm{~Pb}=0.9618 ;{ }^{208} \mathrm{~Pb} /{ }^{206} \mathrm{~Pb}=2.2285\right)(\mathrm{Cummins}$ and Richards 1975$)$ assuming a 2\% uncertainty. Data were reduced using the Krill 007 software developed by Peter Kinny (Curtin University) and plotted using the Isoplot3 add-in for Microsoft Excel (Ludwig 2003). In all cases, no standards were rejected and calculated $2 \sigma$ external spot-to-spot errors for the standards were low.

\section{Results}

\section{Zircon Microstructural Data}

Zircon grains separated from the sample were subdivided into two populations based on petrographic characteristics. Population 1 comprises euhedral orange crystals ranging from $150-500 \mu \mathrm{m}$ in length with length-breadth aspect ratios of between 1 and 3. In PCL, Population 1 grains show typical igneous morphologies and zoning (Fig 4a). In contrast, Population 2 are rounded anhedral to subhedral grains that show a greater colour variation (colourless, yellow, brown), and generally smaller grain size 100 - $300 \mu \mathrm{m}$ long, with aspect ratios $<2$. PCL imaging shows that concentric and sector zoning within Population 2 is commonly truncated by rounded grain margins (Fig. 4b), indicating that many of the grains are relict fragments of originally larger grains. 
Orientation contrast imaging reveals that 20 of the 25 analysed grains from zircon Population 1 contain greyscale changes associated with variations in crystallographic orientation. In contrast, no greyscale differences associated with crystallographic orientation variations are seen in the 26 grains analysed from Population 2.

Panchromatic cathodoluminescence, orientation contrast and EBSD data from a typical grain from Population 1 (grain 5) (Fig. 5) indicate a clear relationship between features identified using the different analytical approaches. In PCL, grain 5 shows a bright, euhedral core, which is transected by dark, relatively diffuse linear domains. This core is surrounded by well-developed, fine-scale oscillatory concentric growth zoning (Fig. 5a). Although the tips of the grain preserve undisturbed PCL zoning, the flanks of the grain show localised disruption and distortion of core and rim compositional zones. On the PCL image these disruptions are either linear, suggesting a planar geometry within the crystal, or take the form of fine, curved dark bands (Fig. 5a).

In the orientation contrast image of grain 5, greyscale variations are seen throughout the whole grain but they tend to be better developed around the grain flanks rather than the grain terminations (Fig. 5b). The greyscale differences are irregular, commonly patchy, and indicate variations in crystallographic orientation within the grain. These orientation variations are confirmed by the cumulative misorientation map obtained from the EBSD data. In the case of grain 5, the $>47,000$ EBSPs used to map the grain, define an orientation variation of $30^{\circ}$ across the grain, which is largely localised at the grain flanks (Fig. 5c,e). The changes in orientation are accommodated by discrete boundaries that correspond to colour changes in the cumulative misorientation map (Fig. 5c) and by increased local misorientation (Fig. 5d). These boundaries represent discrete jumps in misorientation profiles across the grain (Fig. 5f), define the patchy greyscale variations seen in the orientation contrast image 
(Fig. 5b) and are coincident with the complexities seen within the PCL image (Fig. 5c).

Misorientation profiles across the grains show progressive changes as well as sharp steps in crystallographic orientation (Fig. 5f).

When the orientation data are analysed by means of stereographic projection, the changes in crystallographic orientation across the grains are generally systematic and define cumulative dispersions around the zircon c-axis [001] that lie along small circles (Fig. 5g). The majority of misorientation axes associated with $1-15^{\circ}$ misorientation angles are associated with specific boundaries (Fig. 5e) and lie broadly parallel to [001] (Fig. 5h). However, there is a spread in this orientation by up to $20^{\circ}$ for $<5^{\circ}$ boundaries, which decreases to $<5^{\circ}$ for the $>10^{\circ}$ misorientation angles (Fig. $5 \mathrm{~h}$ ). Several clusters of misorientation axes plot away from the c-axis, for example, the shallowly plunging $5-10^{\circ}$ axes in the upper right, upper left and lower left quadrants of the stereonet (Fig. 5h). These are related to specific boundaries within the microstructure (Fig. 5e).

Similar relationships as described for grain 5 are also seen in the analyses from 9 additional grains from Population 1 (Fig. 6), which record cumulative misorientation variations of 3$30^{\circ}$. In all cases, cumulative misorientation and local misorientation maps indicate discrete variations in intragrain crystallographic orientation (Fig. 6a,b) with the grains characteristically preserving gradual and sharp-bounded polygonal orientation domains. These again tend to be localised along, but not restricted to, the flanks of the grains. In many cases (grains 3, 6, 7, 8, 10,11\&12) these variations are associated with dispersion of the crystallographic axes around an axis parallel to the [001] direction (Fig. 6c). As in grain 5, a high proportion of the misorientation axes for these grains are also parallel to [001] (Fig. 6d). In some grains $(3,8,9,10)$ a cluster of misorientation axes also lies parallel to one of the zircon a-axes (Fig. 6c,d), while in grain 13 the $5-10^{\circ}$ misorientation axes lie on a small circle 
that lies $\sim 24^{\circ}$ from the c-axis. This grain is also anomalous in that the crystallographic axes are dispersed around two different small circle distributions.

Cathodoluminescence imaging of Population 2 zircons indicate some complexity within many of the grains associated with compositional growth zoning (e.g. Fig. 4,7a). However, orientation contrast imaging and quantitative orientation analysis by EBSD of the 26 grains that make up Population 2 indicate that there are no intragranular variations in crystallographic orientation (e.g. Fig. 7b). Low-angle orientation boundaries are also absent from these grains (e.g. Fig. 7c).

\section{Zircon Age Data}

SHRIMP U-Pb data show a range of largely concordant ages from the sample that are directly linked to the two populations recognised from their petrographic characteristics. The data from Population 1 show no statistically significant variation between bright PCL cores and compositionally zoned rims and 20 analyses give similar dates that yield a weighted mean ${ }^{206} \mathrm{~Pb} /{ }^{238} \mathrm{U}$ age of $9.28 \pm 0.21 \mathrm{Ma}(\mathrm{MSWD}=0.5$; probability $=0.96)($ Table $2 \&$ Fig. 8$)$. Since this population has the characteristics of igneous zircon, the date is interpreted to reflect the magmatic crystallisation age of this zircon population. In contrast to Population 1, Population 2 comprises sub-to anhedral zircons that yield a range of Archaean to Cambrian dates.

\section{Discussion}

\section{Interpretation of the Zircon Microstructures}

A glomeroporphyritic andesite from Java contains a population of zircon that has magmatic characteristics and a mixed population of xenocrystic grains. The former is interpreted to indicate crystallisation $\sim 9.3 \mathrm{Ma}$ ago, a date consistent with initial development of the Sunda 
Arc (Smyth et al. 2008). The latter population has previously been interpreted to reflect zircon inheritance from a continental fragment of Gondwanan origin that underlies the arc complex from which this sample was derived (Smyth et al. 2007).

The xenocrystic zircons of Population 2 show no evidence of intragrain orientation variations. However, $80 \%$ of the 25 zircons studied from the Miocene magmatic grains of Population 1 (Fig. 4) record complex orientation variations, particularly in their flanks. These orientation variations vary from $c .3-30^{\circ}$ and are accommodated by both progressive bending of the zircon lattice and discrete changes across low-angle boundaries. Similar microstructural features recorded in an Indian Ocean zircon have been previously ascribed to dislocation creep associated with crystal plastic deformation of zircon (Reddy et al. 2007). In this previous study, the analysis of crystallographic dispersion and the geometry of misorientation axes parallel to $<010>$, combined with the orientation of the low angle boundary trace derived from orientation mapping, provided evidence of deformation associated with $<001>\{100\}$ dislocation creep (Reddy et al. 2007). In Population 1 of the Java sample, rotations parallel to $<100>$ are recognised in some grains (Fig. 6d). However, the dominant dispersion and misorientation axes are parallel to [001]. Such a geometry is consistent with dislocation creep associated with $<100>\{010\}$, a slip system recognised in experimental shock deformation experiments on zircon (Leroux et al. 1999). In addition, misorientation axes parallel to $<012>$, which fall on a cone $24^{\circ}$ away from the zircon c-axis, can be recognised in a number of grains (e.g. 5, 12 \& 13) (Fig. 6). There is currently no known slip system in zircon associated with dislocation formation (i.e. misorientation axes) parallel to $<012>$, although similar misorientation data have been reported elsewhere (Reddy et al. 2007). 
Two issues further complicate the simple model of low-angle boundary formation outlined above. Firstly, in grain 5, some low-angle boundaries comprise consistent misorientation axes along their length, despite the boundaries having curved geometries (Fig. 6e). This similarity indicates that these boundaries are more complex than simple tilt boundaries and are necessarily accommodated by changing degrees of tilt and twist components along their length. Secondly, simple models of tilt and twist boundaries (see Fig. 10 of Reddy et al, 2007) predict, for grains where the c-axis lies in the plane of the orientation map, that the traces of boundaries formed by $<001>\{100\}$ and $<100>\{010\}$ should lie parallel to or perpendicular to the trace of the c-axis. Although this is the case for some of the boundaries, many others are oblique to these ideal trace orientations. This is readily explained by lowangle boundaries comprising dislocations of more than one type at a scale that is not resolvable at the scale of the analyses $(1 \mu \mathrm{m})$. Consequently, the spread in the geometry of misorientation axes reflects not only errors associated with the calculation of low-angle misorientations (Prior 1999), but the probable interaction of different slip systems at a submicron scale (Reddy et al. 2007).

Despite these complexities, the majority of the orientation data from Population 1 are consistent with plastic deformation associated with known, rationale, low-index slip systems. The microstructures recognised in the orientation data are therefore interpreted to have developed by dislocation creep. Since the rock from which these zircons were extracted is an undeformed igneous rock, and the zircon from Population 1 has magmatic characteristics, this crystal plasticity is interpreted to have taken place after crystallisation of the zircon but prior to final crystallisation of the host rock. This possibility is now explored further. 


\section{Petrogenetic Model for Zircon Deformation}

A model to explain the petrogenetic evolution of the sample is outlined in Fig. 9. The presence of glomerocrysts and both large and small phenocrysts of compositionally zoned plagioclase and hornblende in a fine-grained matrix (Fig. 9a) indicates a complex igneous history. Glomerocrysts preserving an adcumulate texture provide evidence of low interstitial melt fraction $(<5 \%)$ within plagioclase and hornblende cumulate rocks (Fig. 9b). Grain boundaries within plagioclase have curved geometries and few impingement textures are preserved in any of the glomerocrysts, indicating a significant degree of textural equilibration within the cumulate (Holness 2005). Crystallisation of amphibole / plagioclase cumulates is interpreted to have taken place in the mid-to lower crust during differentiation of arc magmas (e.g. Davidson et al. 2007; Mantle and Collins 2008). Following almost complete crystallisation, plagioclase and hornblende cumulates were disaggregated and remobilised by magmatic rejuvenation of the cumulate. The sieve-textured rims of plagioclase and hornblende, and the growth of new rims of plagioclase around both large glomerocrystic grains and smaller $(\leq 150 \mu \mathrm{m})$ phenocrysts (Fig. 9c,d) is interpreted to reflect reactions between these crystals and the melt, now represented by the fine-grained matrix, probably during rapid decompression of the magma (Humphreys et al. 2006; Pietranik et al. 2006). Following decompression, the fine-grained groundmass indicates rapid, shallow-level, cooling of the magma. This model is similar to open system magmatic processes described from other arcs (Humphreys et al. 2006).

Within this petrogenetic framework, zircon population 1 underwent crystal-plastic deformation. This deformation disrupts oscillatory growth zones at the edges of the grains, and so must have taken place after zircon crystallisation. The absence of deformation features in the fine-grained matrix of the studied rock indicates that zircon deformation must have preceded magmatic rejuvenation and disruption of the cumulate layer that sourced the 
glomerocrysts. Plagioclase within the glomerocrysts is also deformed. Based on these textural relationships, deformation of the plagioclase / hornblende adcumulate and associated population 1 zircon must have taken place within a mid-to-lower crustal cumulate prior to its disaggregation and remobilisation by a later stage melt (Fig. 9b).

Evidence of crystal-plastic deformation is exclusively recorded by grains in the $9.3 \mathrm{Ma}$ zircon of Population 1. The presence of undeformed xenocrystic grains, containing no young $(\sim 10$ Ma) rims, indicates that they were entrained at a late stage in the petrogenetic evolution (Fig. 9). Scavenging of xenocrysts from older Gondwanan basement (Smyth et al. 2007) is therefore interpreted to have taken place after deformation and disruption of the adcumulate, during ascent of the magma to shallow crustal levels (Fig. 9d).

The ability of minerals to deform by dislocation creep in partially molten rocks has been demonstrated experimentally at melt fractions of $<5 \%$ in granitic rocks with a grain size $>10$ $\mu \mathrm{m}$ (Dell'Angelo and Tullis 1988; Dell'Angelo et al. 1987) and reflects the transmission of stresses across the interlocking crystal framework. In this study, the origin of the stresses responsible for the observed deformation is unclear. However for the past $15 \mathrm{Ma}$, the overding plate of the Sunda-Java trench, within which the sample originates has been under a state of compression (Whittaker et al. 2007). Our preferred interpretation is that the low meltfraction, indicated by the glomerocrysts, allowed stresses to be transmitted through the crystal framework such that crystal-plastic deformation of zircon occurred during final stages of adcumulate crystallisation. Zircon deformation therefore reflects tectonic stresses acting on an almost completely crystallised lower crustal cumulate.

\section{Geological Significance}

As discussed in some detail by Reddy et al (2007), the development of microstructures formed by dislocation creep in zircon has fundamental implications for the geochemical 
analysis of zircon and the rocks with which they are associated. At the simplest level, such microstructures will provide multiple diffusion pathways that will modify the bulk diffusion characteristics of zircon. Under most crustal conditions, diffusion in defects is generally easier than volume diffusion, though this difference decreases at increasing temperatures as volume diffusion becomes more competitive. Within the crust, deformation-related microstructures should therefore provide fast-diffusion pathways in zircon that facilitate enhanced chemical exchange in zircon. Such compositional modification has been demonstrated for rare earth elements (Reddy et al. 2006), U and Th (Timms et al. 2006) in zircon. Therefore, the assumption of material transfer solely by volume diffusion may not be valid in many natural zircon. In addition, the dissolution potential will also be expected to increase in zircon grains that contain defects. This has important implications for the modelling of trace element budgets (e.g., in melts systems), which typically assume the sole operation of volume diffusion. Consequently, the results presented here have widespread significance for the assumption for the chemical robustness of zircon and the geochronology and trace element geochemistry of magmas.

Unlike the previous studies of dislocation creep in zircon, there is no evidence for high-strain tectonic activity within the host sample. In this study, microstructures associated with dislocation creep are demonstrated to have formed within magmatic zircon soon after crystallisation, probably associated with tectonic stress transmitted through a low-melt volume crystal framework. The qualitative correlation between crystal-plastic deformation of plagioclase and zircon seen in this study has been recognised previously in other samples (Reddy et al. 2007), and may indicate that zircon deforms at similar conditions to that of plagioclase. Deformation of plagioclase may therefore be an indirect indicator of zircon deformation in crustal rocks. 
This study demonstrates that magmatic zircon has the potential to contain deformationrelated defects, and therefore have modified bulk diffusion and dissolution characteristics. Since zircon usually forms isolated grains, it is unlikely that low-angle boundaries will be removed by subsequent grain boundary migration recrystallisation. Once formed, microstructures associated with dislocation creep of zircon are therefore likely to prevail throughout the history of the zircon, including resedimentation, metamorphism and melting that may affect the host rock. As a result, the a priori assumption that multipath diffusion may only occur in zircons from tectonically deformed areas is flawed and fast diffusion pathways may be expected in zircon from a wide range of geological environments, not just high-strain rocks. Consequently, we recommend that the microstructural analysis of zircon, including igneous grains, is a pre-requisite for the geochemical analysis of zircon. This microstructural analysis need not require a detailed quantitative EBSD approach. In the first instance, the qualitative recognition of deformation-related microstructures in zircon can be achieved by rapid orientation contrast imaging as simply as PCL imaging is used to recognise growth zoning. Indeed the microstructural analysis can be undertaken on samples used for routine PCL characterisation by simply undertaking an additional, commercially available, polishing step.

\section{Acknowledgements}

The Australian Research Council (via Grant DP0664078) and Curtin University (via a Targeted Research Fellowship to SMR) are thanked for funding this research. Auke Barnhoorn and Bill Collins are thanked for constructive reviews of the manuscript. The fieldwork and sample collection in East Java was funded by the SE Asia Research Group, Royal Holloway University of London as part of HRS's PhD studies. Thanks are extended to Robert Hall for PhD supervision, LIPI who provided visas and fieldwork permissions and 
LEMIGAS who acted as counterpart agency. This paper is The Institute for Geoscience Research (TIGeR) publication No. 117.

\section{References}

Cherniak DJ, Watson EB (2003) Diffusion in zircon. In: Hanchar JM, Hoskin PWO (eds) Zircon. Reviews in Mineralogy 53. Min. Soc. Am., Washington, pp 113-143

Chichagov AV, Varlamov DA, Dilanyan RA, Dokina TN, Drozhzhina NA, Samokhvalova OL, Ushakovskaya TV (2001) MINCRYST: a Crystallographic Database for Minerals, Local and Network (WWW) Versions. Crystallography Reports 46:876-879

Compston W, Williams IS, Meyer C (1984) U-Pb geochronology of zircons from lunar breccia 73217 using a sensitive high mass-resolution ion microprobe. Journal of Geophysical Research 89:B525-B534

Cummins GL, Richards JR (1975) Ore lead isotope ratios in a continuously changing earth. Earth Planet. Sci. Lett. 28:155-171

Davidson J, Turner S, Handley H, Macpherson C, Dosseto A (2007) Amphibole "sponge" in arc crust? Geology 35:787-790

Davis DW, Krogh TE, Williams IS (2003) Historical development of zircon geochronology. In: Hanchar JM, Hoskin PWO (eds) Zircon. Reviews in Mineralogy 53. Min. Soc. Am., pp 145-181

Dell'Angelo LN, Tullis J (1988) Experimental deformation of partially melted granitic aggregates. J. Metamorphic Geol. 6:495-515

Dell'Angelo LN, Tullis J, Yund RA (1987) Transition from dislocation creep to meltenhanced diffusion creep in fine-grained granitic aggregates. Tectonophysics 139:325332

Dickin AP (2005) Radiogenic Isotope Geology, vol. Cambridge University Press, pp 508

Grimmer H (1980) A unique description of the relative orientation of neighbouring grains. Acta Crystallography A36:382-389

Hall R (2002) Cenozoic geological and plate tectonic evolution of SE Asia and the SW Pacific: computer-based reconstructions, model and animations. J. Asian Earth Sci. 20:353-431

Hazen RM, Finger LW (1979) Crystal structure and compressibility of zircon at high pressure. Am. Mineral. 64:196-201 
Hinthorne JR, Anderson CA, Conrad RL, Lovering JF (1979) Single-grain ${ }^{207} \mathrm{~Pb} /{ }^{206} \mathrm{~Pb}$ and $\mathrm{U} / \mathrm{Pb}$ age determinations with a $10 \mu \mathrm{m}$ spatial resolution using the ion microprobe mass analyser (IMMA). Chem. Geol. 25:271-303

Holness MB (2005) Spatial constraints on magma chamber replenishment events from textural observations of cumulates: the Rum layered intrusion, Scotland. J. Petrol. 46:1585-1601

Hoskin PWO, Schaltegger U (2003) The composition of zircon and igneous and metamorphic petrogenesis. In: Hanchar JM, Hoskin PWO (eds) Zircon, vol 53. Min. Soc. Am., pp $27-62$

Hough PV (1962) Methods and Means to Recognize Complex Patterns. In: US Patent, vol., US

Humphreys FJ, Bate PS, Hurley PJ (2001) Orientation averaging of electron backscattered diffraction data. J. Microsc. 201:50-58

Humphreys MCS, Blundy JD, Sparks RSJ (2006) Magma evolution and open system processes at Shiveluch Volcano: Insights from phenocryst zoning. J. Petrol. 47:23032334

Kinny PD, Maas R (2003) Lu-Hf and Sm-Nd isotope systems in zircon. In: Hanchar JM, Hoskin PWO (eds) Zircon. Reviews in Mineralogy 53. Mineralogical Society of America Washington, pp 327-341

Leroux H, Reimold WU, Koeberl C, Hornemann U, Doukhan JC (1999) Experimental shock deformation in zircon: a transmission electron microscopic study. Earth Planet. Sci. Lett. 169:291-301

Ludwig KR (2003) User's manual for Isoplot 3.00: a geochronological toolkit for Microsoft Excel. Berkeley Geochronology Center Special Publication 4

Mantle GW, Collins WJ (2008) Quantifying crustal thickness variations in evolving orogens: Correlation between arc basalt composition and Moho depth. Geology 36:87

Nelson DR (1997) Compilation of SHRIMP U-Pb zircon geochronology data, 1996. In, vol. Geological Survey of Western Australia, Perth, Australia

Pietranik A, Koepke J, Puziewicz J (2006) Crystallization and resorption in plutonic plagioclase: Implications on the evolution of granodiorite magma (Gesiniec granodiorite, Strzelin Crystalline Massif, SW Poland). Lithos 86:260-280

Prior DJ (1999) Problems in determining the misorientation axes, for small angular misorientations, using electron backscatter diffraction in the SEM. J. Microsc. 195:217225 
Reddy SM, Timms NE, Eglington BM (2008) Electron backscatter diffraction analysis of zircon: A systematic assessment of match unit characteristics and pattern indexing optimization. Am. Mineral. 93:187-197

Reddy SM, Timms NE, Pantleon W, Trimby P (2007) Quantitative characterization of plastic deformation of zircon and geological implications. Contrib. Mineral. Petrol. 153:625645

Reddy SM, Timms NE, Trimby P, Kinny PD, Buchan C, Blake K (2006) Crystal-plastic deformation of zircon: A defect in the assumption of chemical robustness. Geology $34: 257-260$

Reiners PW (2005) Zircon (U-Th)/He Thermochronometry. In: Reiners PW, Ehlers TA (eds) Low-Temperature Thermochronology: Techniques, Interpretations and Applications. Reviews in Mineralogy 58. Min. Soc. Am., pp 151-179

Smyth HR, Hall R, Nichols GJ (2008) Cenozoic volcanic arc history in East Java, Indonesia: the stratigraphic record of eruptions on a continental margin. In: Draut AE, Clift PD, Scholl DW (eds) Formation and Applications of the Sedimentary Record in Arc Collision Zones. Geol.Soc. Am. Spec. Publ. 436: 199-222

Smyth HR, Hamilton PJ, Hall R, Kinny PD (2007) The deep crust beneath island arcs: inherited zircons reveal a Gondwana continental fragment beneath East Java, Indonesia. Earth Planet. Sci. Lett. 258:269-282

Timms N, Kinny P, Reddy S (2006) Enhanced diffusion of Uranium and Thorium linked to crystal plasticity in zircon. Geochem. Trans. 7:10

Whittaker JM, Müller RD, Sdrolias M, Heine C (2007) Sunda-Java trench kinematics, slab window formation and overriding plate deformation since the Cretaceous. Earth Planet. Sci. Lett. 255:445-457 


\section{Figure Captions}

Figure 1: Tectonic map of Java (modified after Smyth et al. 2008), with regional setting inset (modified after Hall 2002). Sample location is close the boundary between the Southern Mountains Arc and the active Sunda Arc.

Figure 2. Optical photomicrographs of textures in the studied sample. XPL $=$ cross polarised image; $\mathrm{PPL}=$ plane polarised image. $\mathrm{Pl}=$ plagioclase; $\mathrm{Hbl}=$ hornblende. a) Plagioclase glomerocryst within an undeformed finer-grained matrix. Plagioclase grains shows complex oscillatory growth zoning with clear rims overgrowing sieve-textured outer zones. b). A glomerocryst of hornblende grains with compositional growth zones and sieve-textured rims..

c) A polyphase glomerocryst of interlocking plagioclase and hornblende showing adcumulate / heteradcumulate texture. Sutured grain boundaries indicate almost complete crystallization of initial melt phase with melt fractions $<5 \%$. d) Detail of glomerocryst showing an interstitial zircon grain between larger plagioclase grains. In c and d, arrows indicate (i) undulose extinction, (ii) deformation twinning and (iii) transgranular fracture in plagioclase. .

Figure 3: Electron backscatter pattern from one of the analysed zircons showing the empirically derived pattern (a) and the pattern overlain by the indexed solution (blue lines) (b). The Miller indices shown in b correspond to the crystallographic orientations of planes and zones based on the orientation solution obtained for the EBSP. EBSPs are collected over a grid and orientation data are expressed either as c) a variation from a user-specified orientation or d) a local misorientation.

Figure 4: Panchromatic cathodoluminescence images of (a) zircon population 1 and (b) zircon population 2. In a, grain identification numbers refers to EBSD data shown in 
subsequent figures. In $\mathrm{b}, \mathrm{U}-\mathrm{Pb}$ ages correspond to analyses given in Table 2. EBSD data from the marked grain is shown in Fig. 7. .

Figure 5: Microstructural data for grain 5 from zircon Population 1. a) Panchromatic cathodoluminescence image with white ellipse showing the position of a U-Pb SHRIMP age. b) Orientation contrast image where grayscale variations indicate changes in lattice orientation. Different aspects of the EBSD data are shown in c-h. c) Cumulative orientation map showing up to $23^{\circ}$ orientation variation from the core of the grain that corresponds to greyscale variations in $b$ and the disruption recognised in $a$. d) Local misorientation map showing complex low-angle boundary structure. e) Low-angle boundaries (visible in c and d) coloured to show the geometry of the misorientation axes associated with the different boundaries. Colours correspond to the projection of the axes on the stereonet shown beneath the grain. f) Cumulative misorientation along profiles (i) and (ii) in c showing both gradual and stepwise nature of changes in orientation across the grain. Note the total angular variation across the grain approaches $30^{\circ} . \mathrm{g}$ ) Pole figure of major crystallographic planes shows dominant dispersion around the pole to (001). Colours correspond to misorientation scale in c. h) Misorientation axis data showing concentration of data around $<001>$. Other data clusters are responsible for minor dispersions in $\mathrm{g}$. $\mathrm{g}$ and $\mathrm{h}$ are lower hemisphere equal area stereographic projections in the sample coordinate system with number of points shown in lower right.

Figure 6: Orientation maps $(a, b)$ and stereographic projections of crystallographic data $(c, d)$ of selection of zircon grains from Population 1. a) Map coloured for cumulative misorientation $\left(\right.$ in $^{\circ}$ ) relative to a reference orientation indicated by a red cross. Orientation boundaries that exceed $1^{\circ}$ are shown as solid black lines. Non-indexed points that remain after noise reduction are white. b) Low-angle boundary microstructure within each grain 
shown by local misorientation. c) Pole figure of low-index crystallographic planes ((100), (010) and (001) labelled) for every data point shown in a. Colours correspond to orientation variations shown in a. Data commonly show systematic, progressive dispersions around lowindex orientations. d) Plots of misorientation axes between neighbouring data points in A. Black $=1-5^{\circ}, \mathrm{red}=5-10^{\circ}$, blue $=>10^{\circ} . \mathrm{c}$ and $\mathrm{d}$ are lower hemisphere equal area stereographic projections in the sample coordinate system and the number of analyses for each stereonet is shown in lower right.

Figure 7: Panchromatic cathodoluminescence image (a), cumulative misorientation map (b) and local misorientation map (c) of a xenocrystic zircon grain $\mathrm{H}$. The grain shows complex concentric zoning pattern in PCL and has a very consistent orientation, i.e., PCL variations do not correspond to orientation variations and the grain is undeformed. Non-indexed points in the zircon (white) relate to inclusions. Black ellipse shows position of SHRIMP U-Pb age (analysis $\mathrm{H}$ in Table 2).

Figure 8: SHRIMP U-Pb data for young and xenocrystic zircon (Populations $1 \& 2$ respectively). Xenocrysts are generally concordant and show a range of dates (see Smyth et al 2007 for details). The young deformed zircon (insets) are concordant and define a single statistical population with a weighted mean date of $9.28 \pm 0.21$ Ma that is interpreted to be the age of zircon crystallisation. No resolvable age variation is present between cores and rims of individual grains.

Figure 9: Schematic model of the petrogenetic history of the sample within the context of the evolving arc. Cross section through the arc is modified after Smyth et al.(2008). Arrows indicate compression in the arc at the time of crystallisation ( $\sim 10 \mathrm{Ma}$ ago) (Whittaker et al. 2007). Figures a)-e) represent the progressive evolution of the sample and correspond to the positions shown in the cross section. a) Plagioclase, hornblende and zircon crystallisation 
with complex oscillatory growth zones (1). b) Magmatic differentiation and crystal settling. Localised crystal-plastic deformation $(2,3)$ at low melt fraction along with deformation twinning in plagioclase (4) and isolated brittle fracturing (5). c) Disaggregation of adcumulate associated with rejuvenation of the magmatic system results in the incorporation of glomerocrysts and phenocrysts into rejuvenating melt (6). Sieve-textured rims on plagioclase (7) and hornblende (8) formed during magmatic decompression. d) Crystallisation of new plagioclase rims on phenocryst and glomerocrysts (9) and scavenging or inheritance of zircon xenocrysts (10). e) Rapid cooling causes crystallisation of finegrained matrix (11).

\section{Table Captions}

Table 1. SEM and EBSD Settings used in this study.

Table 2. U-Pb SHRIMP data for sample Jhs2Pon4 


\section{Reddy et al / Table 1}

\begin{tabular}{|c|c|}
\hline SEM settings & Philips XL30 W-filament SEM \\
\hline $\begin{array}{l}\text { C coat } \\
\text { Acc. Voltage }(\mathrm{kV}) \\
\text { Working distance }(\mathrm{mm}) \\
\text { Spot size } \\
\text { Tilt }\left(^{\circ}\right)\end{array}$ & $\begin{array}{l}\text { Yes }-c .2 \mathrm{~nm} \text { thick } \\
20 \\
20 \\
\text { Spot size } 5 \\
70\end{array}$ \\
\hline EBSD Settings & HKL Channel 5 SP9 \\
\hline $\begin{array}{l}\text { EBSP collection time per frame (ms) } \\
\text { Background (frames) } \\
\text { EBSP noise reduction (frames) } \\
\qquad \quad \text { (binning) } \\
\text { (gain) } \\
\text { Hough resolution } \\
\text { Match units } \\
\text { Band detection - No. of bands } \\
\text { Step distance ( } \mu \text { m) } \\
\text { Data noise reduction - 'wildspike' removal } \\
\text { - nearest neighbour zero solution extrapolation } \\
\text { - Orientation averaging filter (Humphreys et al, 2001) } \\
\text { (filter size / smoothing angle / artifact angle) }\end{array}$ & $\begin{array}{l}60 \\
64 \\
4 \\
4 \times 4 \\
\text { Low } \\
65 \\
\text { Mincryst card } 5261 \\
8 \\
1 \\
\text { Yes } \\
5 \\
3 \times 3 \text { grid } / 5^{\circ} / 1^{\circ}\end{array}$ \\
\hline
\end{tabular}




\begin{tabular}{|c|c|c|c|c|c|c|c|c|c|c|c|c|c|c|c|}
\hline Analysis & U/ppm & Th/ppm & $\% \mathrm{c}^{206} \mathrm{~Pb}$ & ${ }^{207} \mathrm{~Pb} /{ }^{206} \mathrm{~Pb}$ & $+/-$ & ${ }^{208} \mathrm{~Pb} /{ }^{206} \mathrm{~Pb}$ & $+/-$ & ${ }^{206} \mathrm{~Pb} /{ }^{238} \mathrm{U}$ & $+/-$ & ${ }^{207} \mathbf{P b} /{ }^{235} \mathrm{U}$ & $+/-$ & ${ }^{208} \mathrm{~Pb} /{ }^{232} \mathrm{U}$ & $+/-$ & Age & $+/-$ \\
\hline \multicolumn{16}{|c|}{ Population 1} \\
\hline Pop1. A & 920 & 220 & 0.90 & 0.043636 & 0.005743 & & & 0.001418 & 0.000078 & 0.008529 & 0.001268 & & & 9.1 & 0.5 \\
\hline Pop1. B & 1184 & 334 & 0.52 & 0.041783 & 0.004799 & & & 0.001459 & 0.000077 & 0.008403 & 0.001112 & & & 9.4 & 0.5 \\
\hline Pop1. C & 2387 & 1430 & 1.15 & 0.038229 & 0.004625 & & & 0.001397 & 0.000071 & 0.007366 & 0.001008 & & & 9.0 & 0.5 \\
\hline Pop1. D & 637 & 303 & 1.63 & 0.040076 & 0.008309 & & & 0.001477 & 0.000084 & 0.008161 & 0.001809 & & & 9.5 & 0.5 \\
\hline Pop1. E & 1297 & 408 & 2.41 & 0.043091 & 0.005178 & & & 0.001487 & 0.000077 & 0.008836 & 0.001208 & & & 9.6 & 0.5 \\
\hline Pop1. F & 1355 & 418 & 0.47 & 0.048654 & 0.004654 & & & 0.001503 & 0.000078 & 0.010080 & 0.001154 & & & 9.7 & 0.5 \\
\hline Pop1. G & 1860 & 1409 & 0.15 & 0.051673 & 0.005336 & & & 0.001486 & 0.000076 & 0.010589 & 0.001280 & & & 9.6 & 0.5 \\
\hline Pop1. H & 2112 & 810 & 0.71 & 0.048017 & 0.004013 & & & 0.001428 & 0.000073 & 0.009458 & 0.000975 & & & 9.2 & 0.5 \\
\hline Pop1. I & 1131 & 295 & 1.25 & 0.038871 & 0.004920 & & & 0.001464 & 0.000077 & 0.007847 & 0.001123 & & & 9.4 & 0.5 \\
\hline Pop1. J & 607 & 154 & 1.31 & 0.048129 & 0.006867 & & & 0.001507 & 0.000084 & 0.010003 & 0.001597 & & & 9.7 & 0.5 \\
\hline Pop1. K & 1320 & 526 & 0.89 & 0.043112 & 0.004905 & & & 0.001487 & 0.000077 & 0.008842 & 0.001157 & & & 9.6 & 0.5 \\
\hline Pop1. L & 322 & 90 & 2.32 & 0.042792 & 0.010480 & & & 0.001568 & 0.000099 & 0.009253 & 0.002409 & & & 10.1 & 0.6 \\
\hline Pop1. M & 1183 & 412 & 2.46 & 0.039616 & 0.006251 & & & 0.001356 & 0.000072 & 0.007409 & 0.001280 & & & 8.7 & 0.5 \\
\hline Pop1. N & 1042 & 343 & 1.00 & 0.047675 & 0.008347 & & & 0.001376 & 0.000071 & 0.009048 & 0.001707 & & & 8.9 & 0.5 \\
\hline Pop1. O & 1930 & 797 & 0.00 & 0.046303 & 0.003733 & & & 0.001482 & 0.000074 & 0.009462 & 0.000945 & & & 9.5 & 0.5 \\
\hline Pop1. P & 1142 & 444 & 1.22 & 0.052984 & 0.007416 & & & 0.001405 & 0.000072 & 0.010264 & 0.001590 & & & 9.1 & 0.5 \\
\hline Pop1. Q & 1301 & 497 & 1.15 & 0.056171 & 0.006671 & & & 0.001397 & 0.000071 & 0.010823 & 0.001458 & & & 9.0 & 0.5 \\
\hline Pop1. R & 1959 & 990 & 0.47 & 0.042627 & 0.005146 & & & 0.001400 & 0.000070 & 0.008230 & 0.001121 & & & 9.0 & 0.5 \\
\hline Pop1. S & 1646 & 998 & 1.70 & 0.045457 & 0.005993 & & & 0.001477 & 0.000074 & 0.009259 & 0.001358 & & & 9.5 & 0.5 \\
\hline Pop1. T & 751 & 341 & 8.50 & 0.051635 & 0.013289 & & & 0.001371 & 0.000072 & 0.009761 & 0.002625 & & & 8.8 & 0.5 \\
\hline \multicolumn{16}{|c|}{ Population 2} \\
\hline Pop2. A & 111 & 113 & 0.00 & 0.064321 & 0.001207 & 0.322083 & 0.005537 & 0.101039 & 0.002058 & 0.896080 & 0.026313 & 0.032154 & 0.000891 & 620 & 12 \\
\hline Pop2. B & 75 & 386 & 0.00 & 0.062080 & 0.001633 & 1.683666 & 0.028395 & 0.089355 & 0.002166 & 0.764844 & 0.029013 & 0.029186 & 0.000899 & 552 & 13 \\
\hline Pop2. C & 112 & 67 & 0.00 & 0.182942 & 0.001679 & 0.166274 & 0.001595 & 0.520843 & 0.009771 & 13.137743 & 0.287593 & 0.144901 & 0.003268 & 2680 & 15 \\
\hline Pop2. D & 499 & 37 & 0.08 & 0.063993 & 0.001363 & 0.021719 & 0.002491 & 0.109894 & 0.001925 & 0.969637 & 0.028333 & 0.032513 & 0.003776 & 672 & 11 \\
\hline Pop2. E & 153 & 105 & 0.26 & 0.066572 & 0.002493 & 0.207600 & 0.005350 & 0.174035 & 0.003231 & 1.597467 & 0.070020 & 0.052567 & 0.001700 & 1034 & 18 \\
\hline Pop2. F & 158 & 103 & 0.08 & 0.184243 & 0.001445 & 0.171882 & 0.002052 & 0.516270 & 0.009248 & 13.115001 & 0.267987 & 0.135626 & 0.003029 & 2691 & 13 \\
\hline Pop2. G & 139 & 78 & 0.04 & 0.180104 & 0.001622 & 0.152244 & 0.002334 & 0.504448 & 0.009105 & 12.526844 & 0.264977 & 0.137023 & 0.003359 & 2654 & 15 \\
\hline Pop2. H & 147 & 80 & 0.00 & 0.188434 & 0.001571 & 0.152827 & 0.001391 & 0.405818 & 0.007371 & 10.543663 & 0.220494 & 0.114049 & 0.002424 & 2729 & 14 \\
\hline Pop2. I & 56 & 24 & 0.77 & 0.054052 & 0.013825 & 0.122884 & 0.031282 & 0.096423 & 0.002531 & 0.718611 & 0.187096 & 0.027837 & 0.007131 & 593 & 15 \\
\hline Pop2. J & 166 & 159 & 0.13 & 0.177327 & 0.001648 & 0.257477 & 0.002601 & 0.506401 & 0.009202 & 12.381451 & 0.265190 & 0.135750 & 0.002952 & 2628 & 15 \\
\hline Pop2. K & 32 & 48 & 0.51 & 0.072475 & 0.010579 & 0.453340 & 0.025029 & 0.185307 & 0.004687 & 1.851752 & 0.280024 & 0.056016 & 0.003476 & 1096 & 25 \\
\hline Pop2. L & 844 & 1429 & 1.05 & 0.093284 & 0.001093 & 0.143824 & 0.002161 & 0.169228 & 0.002863 & 2.176612 & 0.047348 & 0.014374 & 0.000327 & 1008 & 16 \\
\hline Pop2. M & 280 & 108 & 0.02 & 0.181374 & 0.001103 & 0.103709 & 0.001389 & 0.500205 & 0.008666 & 12.509072 & 0.238481 & 0.134263 & 0.003003 & 2665 & 10 \\
\hline Pop2. N & 112 & 130 & 1.25 & 0.053759 & 0.006828 & 0.348392 & 0.015942 & 0.109518 & 0.002255 & 0.811777 & 0.106489 & 0.032972 & 0.001674 & 670 & 13 \\
\hline Pop2. O & 507 & 236 & 0.15 & 0.080899 & 0.001091 & 0.137543 & 0.001984 & 0.202548 & 0.003491 & 2.259295 & 0.052354 & 0.059835 & 0.001363 & 1189 & 19 \\
\hline
\end{tabular}

Errors are $1 \mathrm{~s} . \% \mathrm{c}^{206} \mathrm{~Pb}$ is the percentage of common ${ }^{206} \mathrm{~Pb}$ in the total 


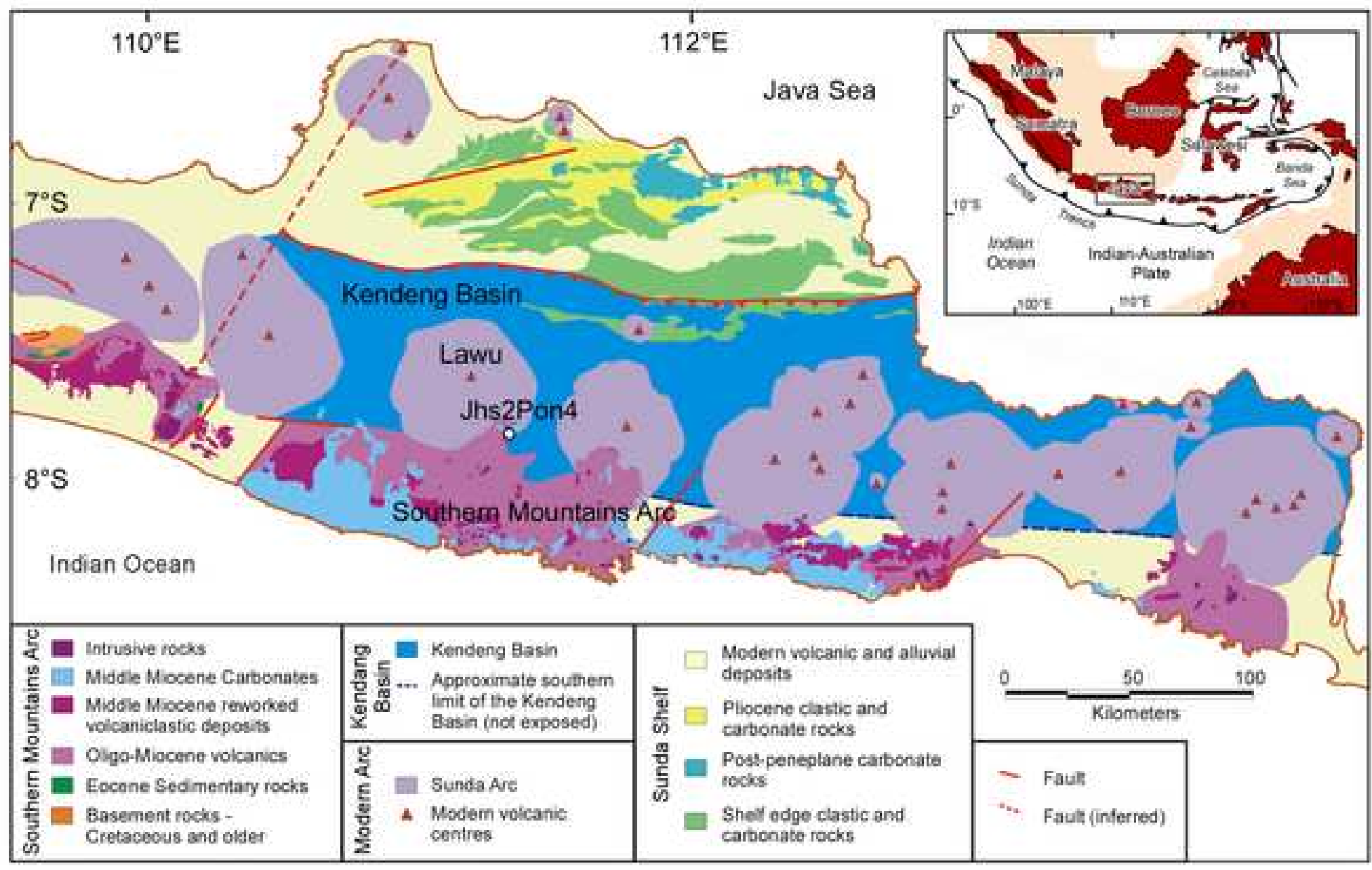

Reddy et al. / Fig.1

Colour figure in print and online 
Click here to download high resolution image

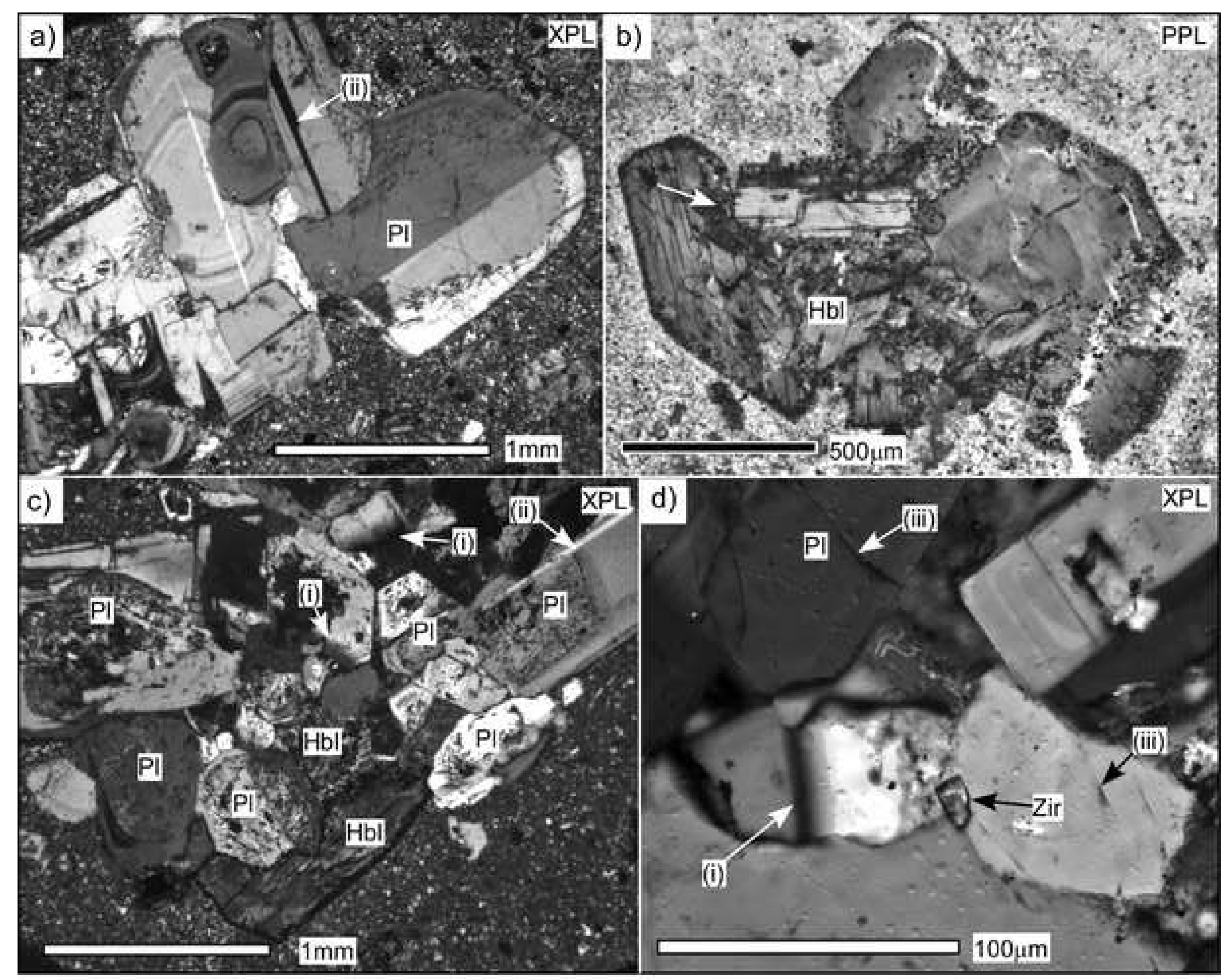

Reddy et al / Fig. 2 
Click here to download high resolution image

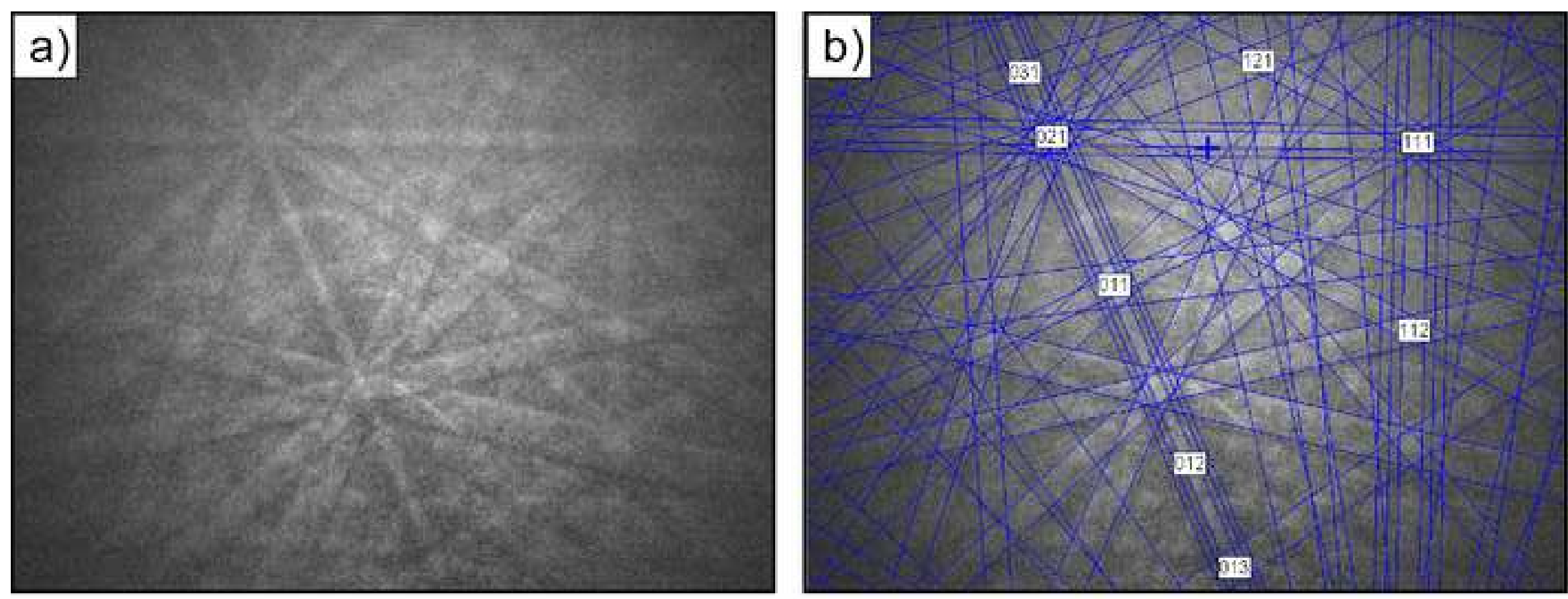

c)
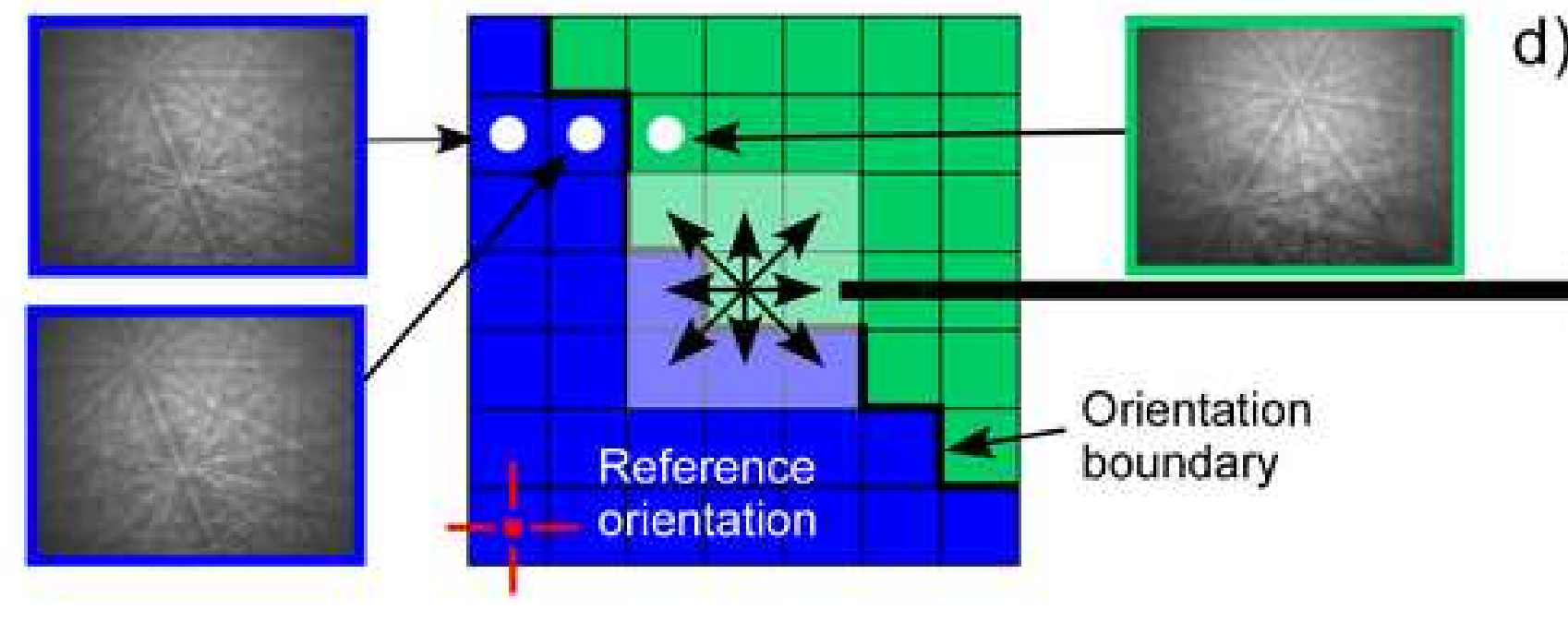

d)

Reddy et al., Figure 03

For colour reproduction online \& print

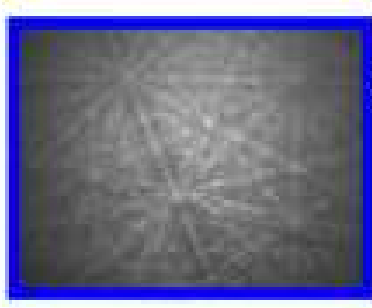

\section{Orientation \\ boundary}

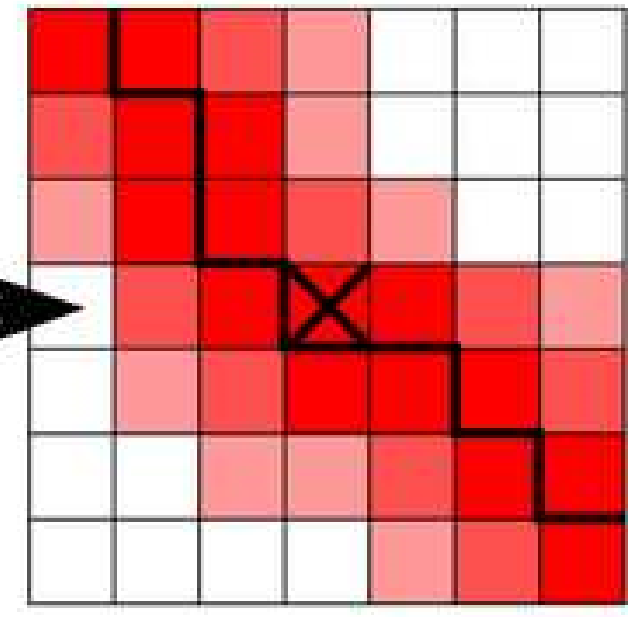




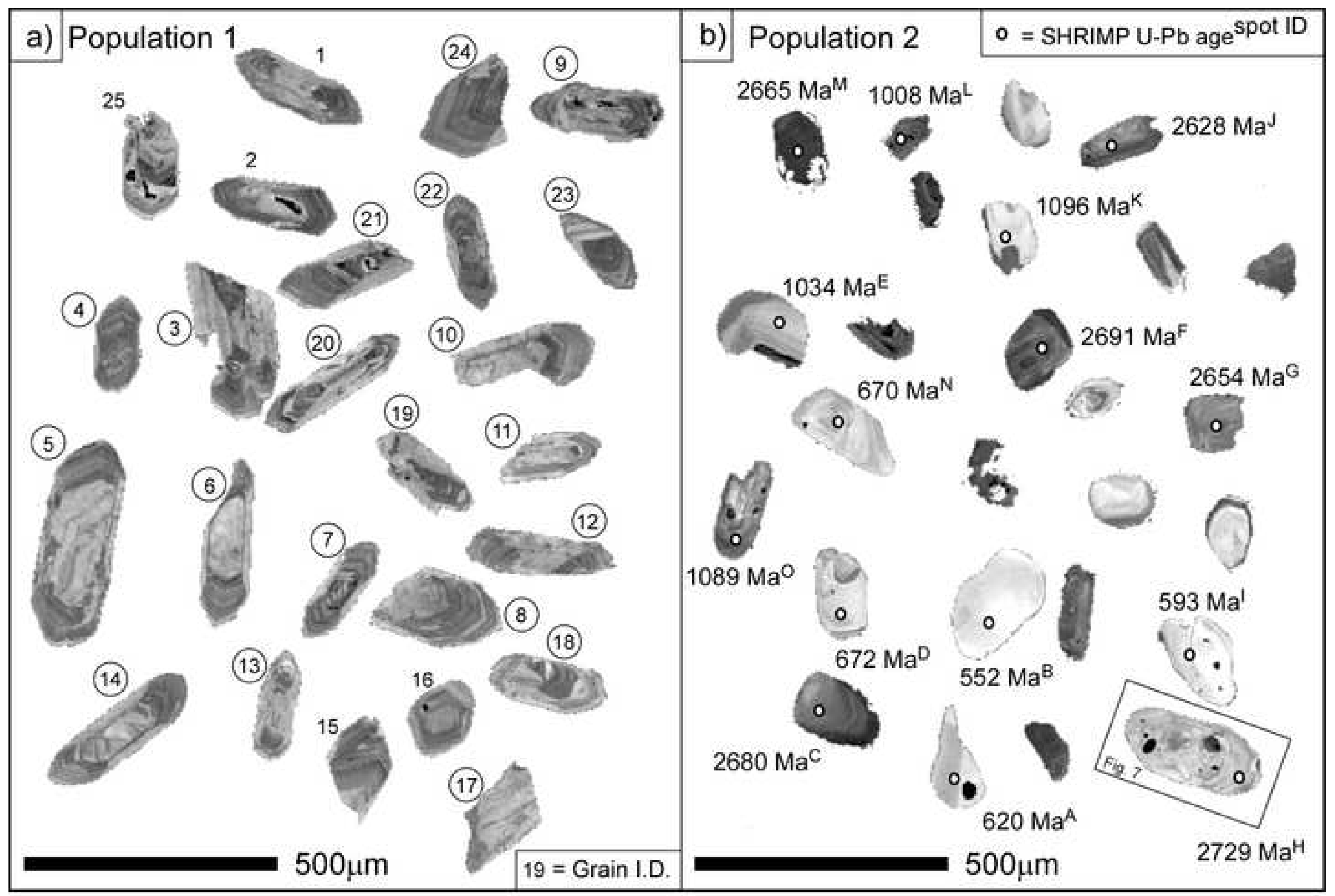

Reddy et al/ Figure 4 


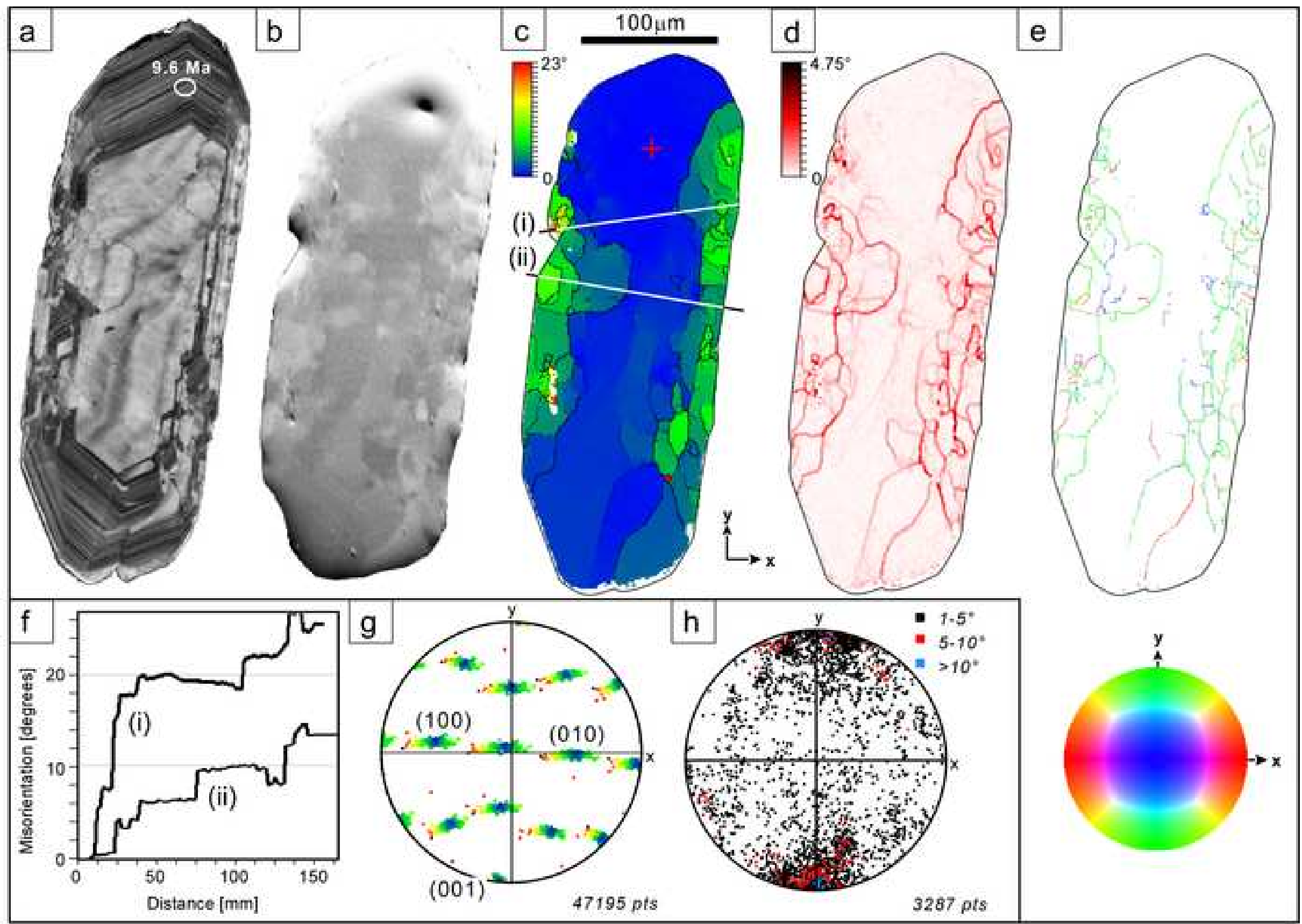

Reddy et al./ Figure 5

For colour reproduction online \& print 
Fig 06

Click here to download high resolution image

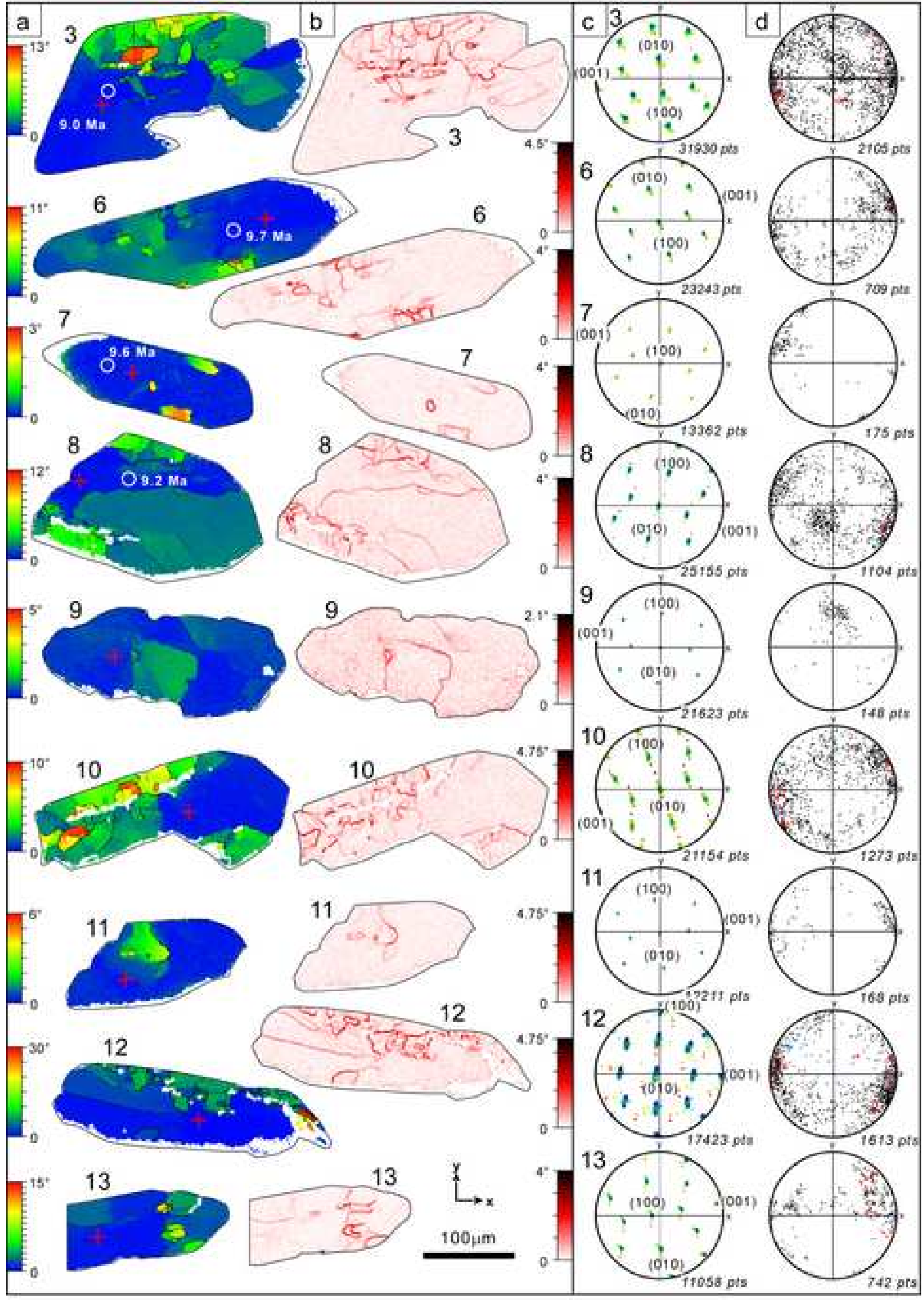

Reddy et al., Figure 6

For colour reproduction online \& print 


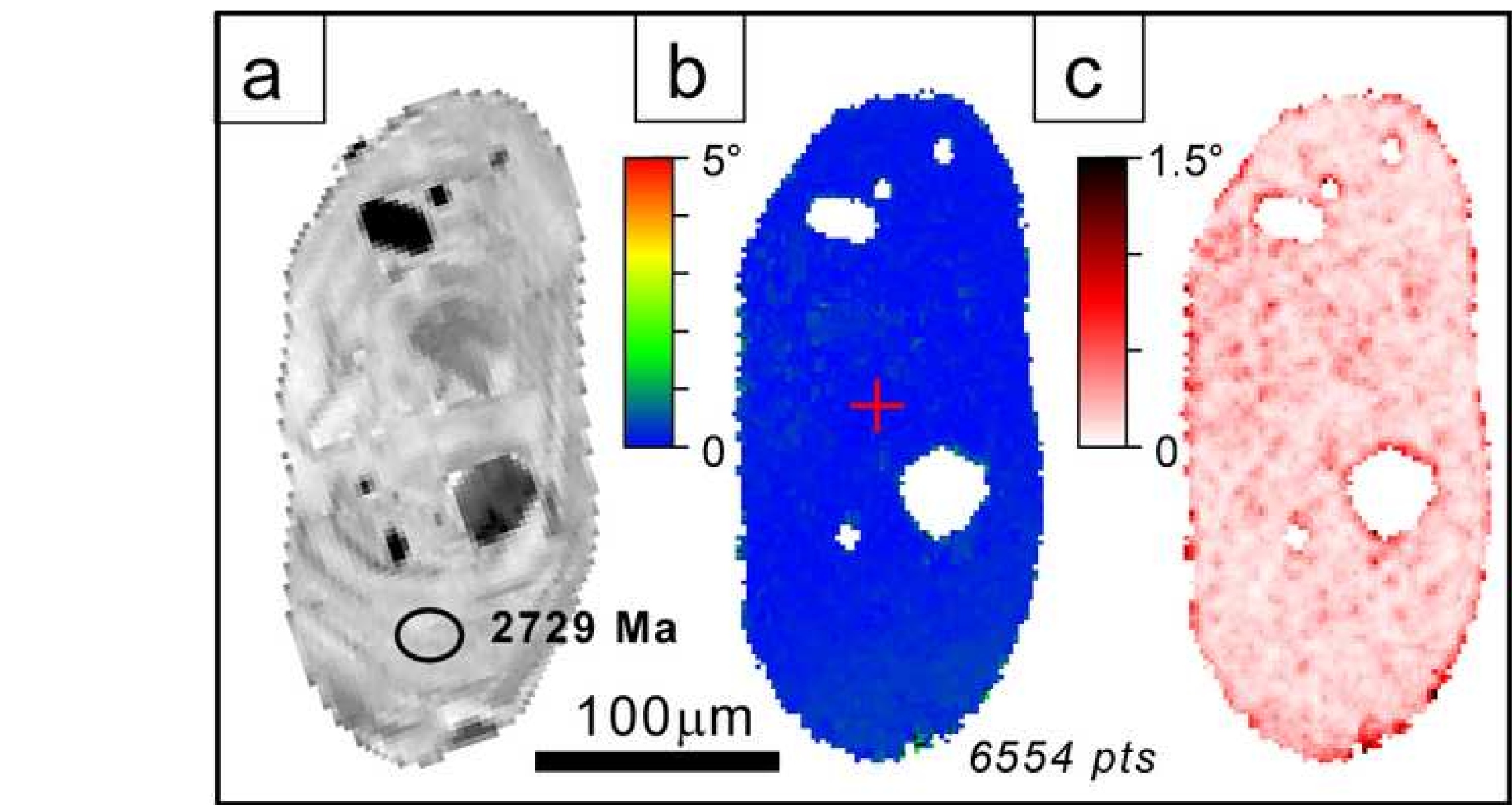

\section{Reddy et al., Figure 7 For colour reproduction online \& print}




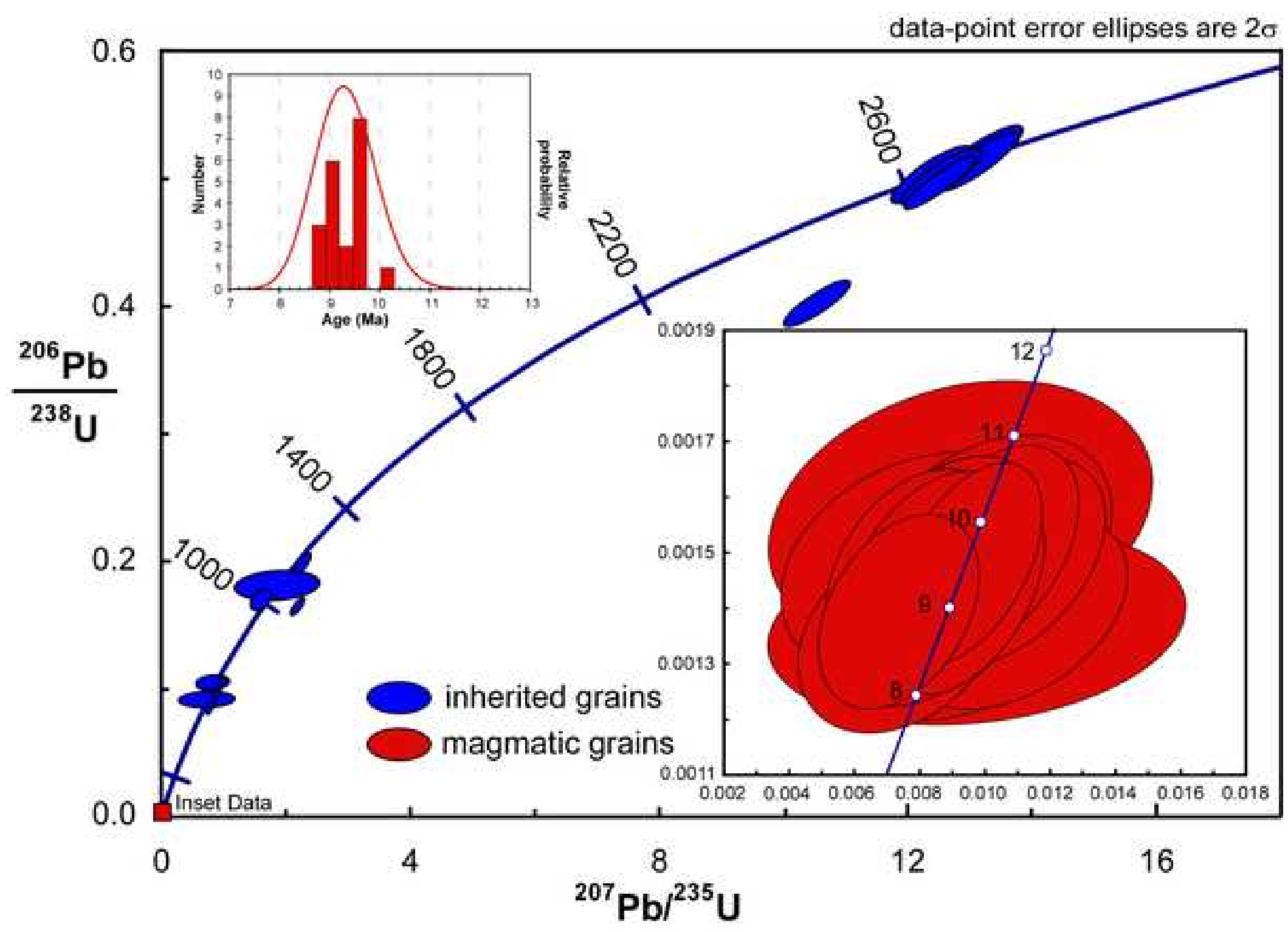

Reddy et al / Fig 8

Colour figure in print and online 

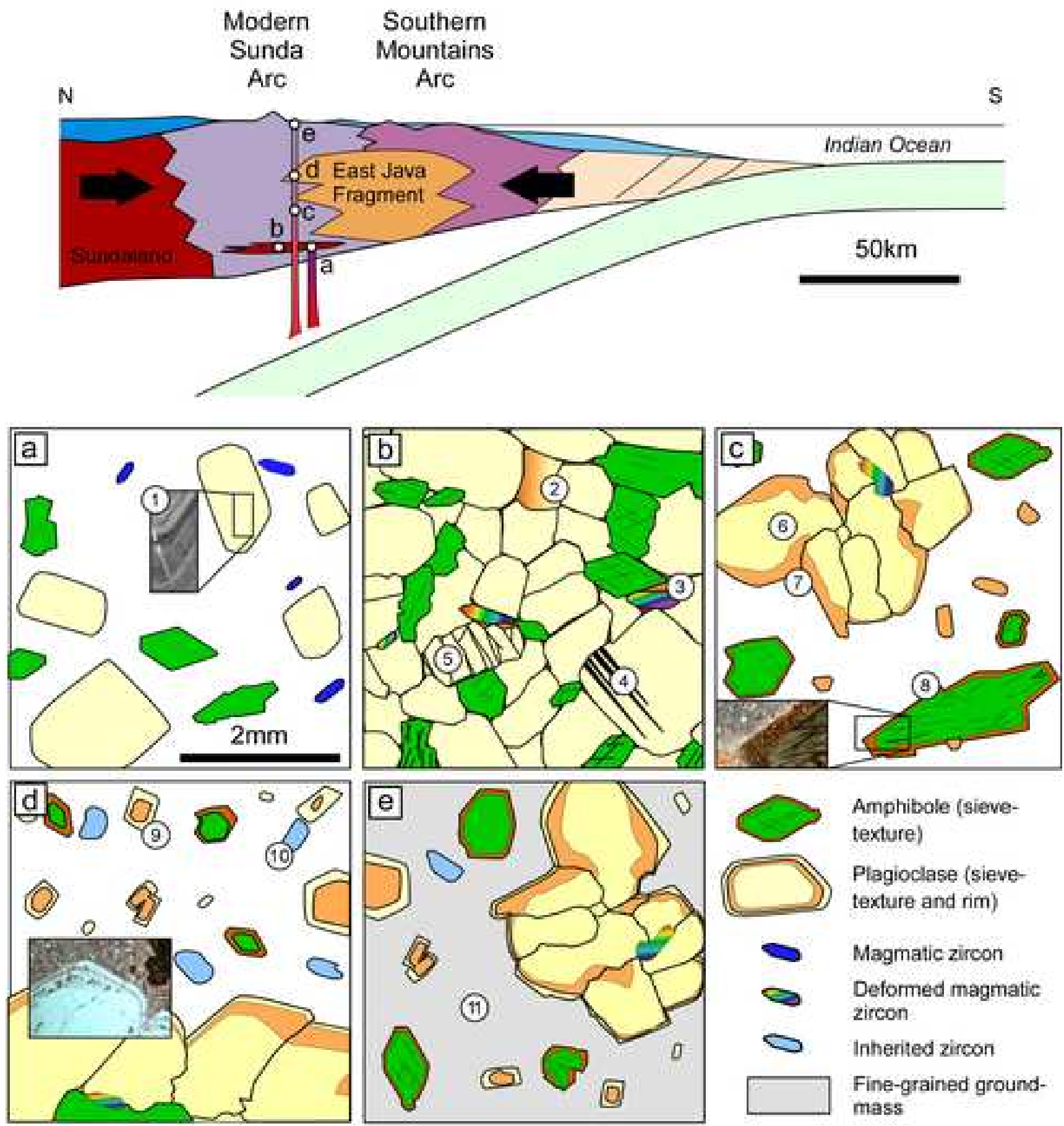

Amphibole (sievetexture)

Plagioclase (sievetexture and rim)

Magmatic zircon

Deformed magmatic zircon

Inherited zircon

Fine-grained groundmass

Reddy et al. / Figure 9

Colour figure in print and online 